\title{
Underestimating the Reader: The De Thou Manuscript of the Heptaméron
}

\author{
DEBORAH N. LOSSE
}

Over four decades ago, Michel François called our attention to two manuscripts of Marguerite de Navarre's Heptaméron by Adrien de Thou: one, the well-known Français 1524 at the Bibliothèque nationale, and another, No. 242 in the collection of John Pierpont Morgan. ${ }^{1}$ In a largely descriptive article, François mentions only in passing the two most interesting aspects of De Thou's work: his desire to make the text more readable and his alteration of the framework for each nouvelle. Although literary historians tend to prefer the De Thou manuscript (FR. 1524), signed and dated 1553, to Claude Gruget's edition, published in 1559, in large part because Gruget deleted or altered some of Marguerite's most critical statements about the clergy, there are some serious drawbacks with the De Thou manuscript. ${ }^{2}$ The weakness of his manuscript lies not in the generally faithful transcription of the tales, but rather in his alteration of the framework and in his attitude toward the reader. ${ }^{3}$

In his notice to the reader introducing the Heptaméron, Adrien de Thou echoes Du Bellay's cry for the enrichment and purification of the French language. But for De Thou, the goal of linguistic reform is beyond a doubt the facilitation of the reading process. He is most immediately concerned with the reader's response to the Heptaméron. His avis au lecteur stresses again and again the visual reception of the text:

D'autant lecteur qu'il avient souvent que mesmes les meilleurs espritz sont detournez de la lecture ou impression, tant belle et bien pinte soit elle, mal orthographée qui procede ordinairement d'une non chalence trop inepte, ou d'une extreme ignorance. ...

He warns his readers that he will break from common orthographic practice to follow a consistent system of spelling:

... de prime entrée vous ai bien voulu avertir que sciemment, et de propos délibéré n'ay suyvi l'orthographe vulgaire, ne me pouvant persuader qu'un visage commun se doive recevoir pour loy immuable, quand oculairement on le void contraire à la verité, souz protection de laquelle me suis volontiers soumis à 
l'opinion de quelques gens de bon jugement, qui maintienent le naif de notre langue françoyse ne se pouvoir mieus exprimer, que par ecriture conforme à la prononciation [emphasis added].

Readability (lisibilité) is then, from De Thou's point of view, the first criterion for engaging the reader - not humor, nor inventiveness, but ease in reading the written page. The major portion of the avis au lecteur leads us to believe that we are dealing with the ideal copyist/editor, who leaves aesthetic concerns for the author to resolve and sets about correcting mechanical problems impeding the reading process.

Almost as an afterthought, De Thou advises the reader that his changes have not been limited to orthographic corrections, but that he has tried to enhance the literary appeal of the text by emphasizing the link between Marguerite's work and her model, Boccaccio's Decameron: "Au surplus, pour faire conformer ces Nouvelles de la Royne de Navarre, soeur du Roy Françoys premier, a celles de Jan Boccace, j'ai mis à chacune son sommaire, ou argument. ..."

While we can assume that the summaries are just another tool to help the reader, we can only interpret his decision to rework the framing of the stories as a criticism of Marguerite's aesthetic judgment. He quite clearly states that his alterations in the framing have enhanced the aesthetic appeal of the nouvelles. Faithful to the manuscripts from which he is working, he omits nothing, "mais plus tot aioutant au commencement et à la conclusion des nouvelles, pour lui donner telle grace, que si elles se lisent tumultüerement, le commencement ne semble aiouté, ny la fin tronquée" (emphasis added). From copyist/editor, De Thou has turned collaborator.

A close examination of the existing manuscripts of the Heptaméron prepared mid-sixteenth century shows that, aside from minor variants in the starting points of a few tales, the framing remains consistent. ${ }^{4}$ De Thou alone makes significant changes in the framework of the tale. Let us look at the nature and extent of his changes in an effort to draw some conclusions.

At first glance, the changes in the framing seem purely mechanical and of little consequence. In the manuscripts of the Heptaméron, all the discussion of the tale as well as the introduction to the new tale is placed at the tale's conclusion. Closure and transition are combined in a single discussion among the devisants. From the standpoint of structural unity and aural reception, this format has definite advantages. Each new tale begins with a similar formula:

En la ville d'Amboise y avoit ung mulletier qui servoit la roine de Navarre. ... (Nouvelle 2) ${ }^{5}$

En la comté d'Alletz, y avoit ung homme, nommé Bornet, qui avoit espouzé une honneste femme de bien. ... (Nouvelle 8)

En la ville de Pampelune, y avoit une dame estimée, belle et vertueuse, et la plus chaste et devote qui fust au pays. (Nouvelle 35) 
The audience clearly recognizes the opening of the new tale by the formula. ${ }^{6}$ De Thou interferes with the formulaic structure of the frame. Perhaps because he does not feel that the structure of the nouvelle is supple enough to tolerate a shift in subject matter, he cuts off the tale at the close of the commentary and begins the new tale with the introduction.

Such a radical change in framing was no doubt inspired by De Thou's desire to follow Boccaccio, for the Decameron, in the Italian editions and in Le Maçon's translation of 1545, places the introduction to the tale and tale together in the same chapter. There remains a basic difference in structure that De Thou chooses to overlook or sacrifice in his attempt to follow the model. The introductions to the individual tales of Boccaccio's work are static and straightforward, while the lively dialogues and animated exchange between devisants found in the Heptaméron are absent in Boccaccio's frame and exist only in the narrative action. By altering the story frames, De Thou deprives the dialogue/commentary of much that brings it to life and sets it apart from the Italian model.

The rupture in the dialogue/commentary, necessitated by the abrupt termination of the dialogue and resumption under a new chapter heading, almost always forces a switch from direct discourse (found in the FR 1512, 1515, and 1520 manuscripts) to reported speech or action. The transformation to indirect discourse results in the shift to more remote past tenses and a consequent increase in the distance between narrator and reader. Seymour Chatman has demonstrated to what extent reported speech demands the intervention of the narrator, and in the instance of De Thou's manuscript, the intervention of the primary narrator robs the actors (the devisants or secondary narrators) of their play."

The twenty-sixth tale serves as an example of the switch from showing to telling, or from unmediated presentation to mediated reporting. In the majority of manuscripts, Saffredent leads into the twenty-seventh tale in the following manner: "Or je vous prie, ... laissons ceste dispute, car elle sent plus sa predication que son compte" (L'Hemptaméron, ed. François, p. 221). His statement is terse and vigorous. Having to report rather than represent the proceedings, De Thou transforms the brief statement into a rather complex compound sentence aimed at relating rather than showing Saffredent's state of mind: "Saffredan connut à la contenance de la plus part des assistans, que cette dispute commençoit fort à les ennuyer, pour ce qu'elle sentoit plus sa predication, que son conte, ne retenant rien ou bien peu, de la familiarité tant requise ès discours et devis communs" (Français 1524, p. 194). Here we have an excellent illustration of the fact that it takes longer to tell than to show. Saffredent's impatience shows up far better in his brief utterance than in the narrator's long-winded account.

De Thou's decision to break up the frame between two tales instead of leaving it intact at the end of each tale necessitates an expansion of the frame. 
In the above example, the added length is in part due to the fact that the statement serves as a recapitulation of what occurs in the preceding tale. Should the reader interrupt his reading at the end of one tale, a brief restatement serves to reorient him at the start of the next tale.

The most extensive example of textual expansion and repetition in the De Thou manuscript occurs in the forty-fifth and forty-sixth tales. The 1512 text, very similar to the 1515 and 1520 manuscripts, states: "Si l'amour reciproque, dist Parlamente, ne contente le cueur, tout aultre chose ne le peult contenter" (L'Heptaméron, ed. François, p. 308). De Thou furnishes a long elaboration of Parlemente's brief statement:

Afin que les paroles d'Hircan ne fussent prises aussi crument qu'il les avoit proferées, Parlamente sa femme voulut bien suppléer leur defectuosité, faisant entendre à la compagnie que graces à Dieu ilz avoient tous deus vecu jusques à present en si grande amytié que jamais l'un ne fut plus mal aysé à contenter que l'autre, et que ses paroles bien entenduës, ne denigroient en rien son honneur, mais confirmoient la bonne opinion qu'elle avoient tousiours euë de luy. Inferant de là que si l'amour ne contente le cueur, toute autre chose ne le peut contenter.

(Français 1524, pp. 271-72)

As an overt, omniscient narrator, De Thou attributes motives to Parlamente that Marguerite had left for the reader to reconstruct. ${ }^{8}$ Having promised to add grace to Marguerite's text, he has instead sacrificed nuance for explicit commentary.

De Thou's lack of confidence in the reader's ability to grasp the text becomes apparent in the forty-sixth tale, in which the "punch line" depends on a pun on the name of the monk, De Valé. The monk follows a young wife up into the attic. Fearful of his intentions, the woman gives him a kick in the stomach and shouts. "Devallez, devallez!" (L'Heptaméron, ed. François, p. 309). Not trusting the reader to understand the word play, De Thou changes the trait saillant, the distinctive feature of the genre, to read "Monsieur de Valé, devalez!"9 In his desire to guide the reader and to clear up ambiguity, De Thou undermines the aesthetic appeal of the text whose success he wants to assure.

Emile V. Telle pointed out long ago that Marguerite's greatest contributions to the nouvelle were in the area of dramatic interest and tension. ${ }^{10}$ Nowhere do we see the conflicts resulting from the interaction of characters and diverse points of view better than in the dialogues between the devisants at the end of each tale. As I have suggested, the change in framing necessitates a shift to reported speech. As a result, the reader is faced with reported conflict rather than enacted conflict and with reported feelings rather than experienced sentiment.

The thirteenth tale provides an illustration of this deflation of dramatic interest in the frame. Frustrated by the reaction of the other devisants, 
Saffredent openly expresses his anger: "Mais n'en parlons plus, affin que ma collere ne face desplaisir, ny à moy, ny à autre" (L'Heptaméron, ed. François, p. 97). In De Thou's version, we experience none of the urgency in Saffredent's reported anger: "A fin que la colere de Saffredan ne feit deplaisir, ny à luy, ny à autre, laisserent ce propos ..." (Français 1524, p. 81). In this instance, De Thou has avoided repeating previously stated material, but he has removed overt interpersonal conflict through the intervention of the primary narrator.

One need only contrast the rather static narration forming the bulk of the prologue to the Heptaméron with the dynamic exchange of opinions following each tale to understand that the aesthetic value of Marguerite's framework lies in the interaction of personalities. De Thou's unfortunate reframing of the tales necessitates the suppression of substantial segments of these dialogues and consequently diminishes those sections in which Marguerite had made significant innovations in the genre.

What can we conclude from De Thou's redundant alterations in the framework? We might recall Roland Barthes's definition of the readable text as one that eliminates ambiguity and indeterminacy by supplying redundant, unequivocal interpretations of the action. The author of the readable text is obsessed with communicating a single, unambiguous meaning. ${ }^{11}$ De Thou's cautious apology for altering the Heptaméron manuscripts confirms his. preoccupation with communication. Hoping to facilitate interpretation, he underestimates the reader's ability to reconstruct the text on his own.

By trying to fill the gaps, the moments in the reading process at which questions arise in the reader's mind, De Thou intervenes at the very moment the communication process is beginning to take place. Wolfgang Iser explains that it is the gaps - the fundamental asymmetry between text and reader - that give rise to communication in the reading process. The gaps encourage the reader to make projections, and it is at this point that the reader begins to function as a producer of the text. ${ }^{12}$

The reader's production of the text is not of prime concern to De Thou. Fearful that the reader will be put off (detourné) by textual difficulties, he views his role as intermediary between the product, Marguerite's text, and the consumer, her reader. Failing to understand that ambiguity stimulates rather than deters participation in the reading process, he undermines the dynamic interaction between text and reader.

Arizona State University 


\section{Notes}

1 Michel François, "Adrien de Thou et l'Heptaméron de Marguerite de Navarre," Humanisme et Renaissance, 5 (1938), 16-36.

2 François, p. 35. Pierre Jourda, Marguerite d'Angoulême, Duchesse d'Alençon, Reine de Navarre (Paris: Honore Champion, 1930), p. 659.

3 In fact, from the standpoint of the modem researcher, the splendid humanist handwriting of Adrien de Thou makes his manuscript the most readable of the Heptaméron manuscripts at the Bibliothèque nationale. I am comparing De Thou's manuscript Français 1524 with the following manuscripts: Français 1512, the text for Michel François's fine edition of the Heptaméron (Paris: Garnier Frères, 1967), Français 1515 and Français 1520.

4 For example, the second tale of the first day begins "Il me semble, mes dames, ..." in Français 1515 and 1520 , but with "En la ville d'Amboise ..." in Français 1512.

5 Marguerite de Navarre, L'Heptaméron, ed. M. François (Paris: Garnier Frères, 1967), p. 18. Since François's edition is based on the Français 1512 manuscrpt, I shall refer to it, when citing a text other than the De Thou manuscript. The 1512,1515 , and 1520 manuscripts are very similar, with minor variations in spelling and wording.

6 Janet M. Ferrier has demonstrated Marguerite's debt to the fifteenth-century French nouvelle in her absolute insistence on the topological placement of the tale and in the economy of detail in the description of the characters. Forerunners of the French Novel: An Essay on the Development of the Nouvelle in the Late Middle Ages (Manchester: Manchester University Press, 1954), p.30.

7 Seymour Chatman, Story and Discourse: Narrative Structure in Fiction and Film (Ithaca/London: Cornell University Press, 1978), pp. 199-200.

8 One of the signs of overt narration in Chatman's characterization of the overt narrator is "the open explanation of the gist, relevance, or significance of a story element," Story and Discourse, p. 228.

9 Werner Söderhjelm, in La Nouvelle francaise au XVe siècle (Paris: Honoré Champion, 1910), identified the catastrophe inattendue or surprenante as the distinguishing characteristic of the fifteenthcentury nouvelle, p. ix. Jean Rychner used the term trait saillant to refer to the brusk, unexpected turn in the nouvelle. Review of Forerunners of the French Novel by Janet M. Ferrier, Bibliotheque d'Humanisme et Renaissance, 17 (1955), pp. 332-34. Paul Zumthor prefers the term pointe in Essai de poétique médiévale (Paris: Editions du Seuil, 1972), p. 400. See also Armine Avakian Kotin, Narrative Imagination: Comic Tales by Philippe de Vigneulles (Lexington, Kentucky: University Press of Kentucky, 1977), pp. 14-15.

10 Emile V. Telle, L'Oeuvre de Marguerite d'Angoulême, Reine de Navarre, et la querelle des femmes (Toulouse: Imprimerie Toulousaine Lion et Fils, 1937), p. 139.

11 Roland Barthes, S/Z (Paris: Editions du Seuil, 1970), pp. 10-12, 85-86. See also Susan Rubin Suleiman's discussion of "Redundancy and the Readable Text," Poetics Today, I, 3 (1980), pp. 118-41.

12 Wolfgang Iser, The Act of Reading: A Theory of Aesthetic Response (Baltimore/London: Johns Hopkins University Press, 1978), p. 34. The term reader, as applied in this study, refers not to Marguerite's contemporaries, but to a presence or construct that "embodies all those predispositions necessary for a literary work to exercise its effect - predispositions laid down not by any empirical reality, but by the text itself" (Iser, p. 34). 